\title{
СТРУКТУРНО-ІНФОРМАЦІЙНА МОДЕЛЬ МЕДИЧНОЇ ІНФОРМАЦІЙНОЇ СИСТЕМИ ДЛЯ ДІАГНОСТИКИ І ЛІКУВАННЯ ХВОРИХ 3 РУХОВИМИ ПАТОЛОГІЯМИ
}

\author{
О. Ю. Азархов ${ }^{1}$, С. М. Злепко ${ }^{2}$, Д. Х. Штофель ${ }^{2}$ \\ ПУ «Санаторій «Металург» ${ }^{1}$ \\ Вінницький національний технічний університет ${ }^{2}$
}

В статті представлена авторська розробка - модель інформаційної системи для лікування хворих 3 патологією рухового апарату, що характеризується дворівневим контролем медичних призначень. Останнє значно підвищує якість медичного обслуговування населення.

Ключові слова: опорно-руховий апарат, реабілітаційно-відновлювальний процес, інформаційна модель.

\section{СТРУКТУРНО-ИНФОРМАЦИОННАЯ МОДЕЛЬ МЕДИЦИНСКОЙ ИНФОРМАЦИОННОЙ СИСТЕМЫ ДЛЯ ДИАГНОСТИКИ И ЛЕЧЕНИЯ БОЛЬНЫХ С ДВИГАТЕЛЬНЫМИ ПАТОЛОГИЯМИ}

\author{
А. Ю. Азархов ${ }^{1}$, С. М. Злепко ${ }^{2}$, Д. Х. Штофель ${ }^{2}$ \\ ЧУ «Санаторий «Металлуре»" \\ Винницкий национальный технический университет ${ }^{2}$
}

\begin{abstract}
В статье представлена авторская разработка - модель информационной системы для лечения больных с патологией двигательного аппарата, характеризующаяся двухуровневым контролем медицинских назначений, что значительно повышает качество медицинского обслуживания населения.
\end{abstract}

Ключевые слова: опорно-двигательный аппарат, реабилитационно-восстановительное лечение, информационная модель.

\section{STRUCTURAL-INFORMATIVE MODEL OF MEDICAL INFORMATICS SYSTEM FOR DIAGNOSTICS AND TREATMENT OF PATIENTS WITH MOTIVE PATHOLOGIES}

\author{
O. Yu. Azarkhov' ${ }^{1}$, S. M. Zlepko², D. Kh. Shtofel ${ }^{2}$ \\ Private sanatorium «Metalurh»" \\ Vinnytsia National Technical University ${ }^{2}$
}

The informative system model for treatment of motive system pathology patients is developed, which is characterized by two-level medical settings control that considerably promotes the medical service quality.

Key words: motive system, rehabilitation-restoration treatment, infor mative model.

Вступ. Відомо, що до складу інформаційної системи включають: технічні (апаратні) засоби реєстрації й обробки даних, програмне, інформаційне забезпечен ня, а також відповідний обслуговуючий персонал. Внутрішню інформаційну структуру утворюють чотири складові частини інформаційних систем: засоби реєстрації і збору інформації; засоби передачі даних і повідомлень; засоби збереження інформації; засоби аналізу, оброблення та представлення інформації.

Сучасні тенденції розвитку медичних інформацій(C) О. Ю. Азархов, С. М. Злепко, Д. Х. Штофель, 2011 них систем (MIC), навіть орієнтованих на один клас захворювань або одну категорію хворих із певною патологією, полягають у переході від вузькоспеціалізованості до багатофункціональності, до комплексних і відкритих інформаційних структур, що забезпечують інтеграцію різнопланових систем і підсистем в єдиному інформаційному просторі.

Серед першочергових потреб практичної медицини, забезпечення яких пов'язано з виявленням механізмів управління руховою діяльністю, відзначається пробле- 
ма створення методик реабілітації хворих з порушеннями у функціонуванні опорно-рухового апарату (OPA).

Метою даної роботи $є$ розробка й обгрунтування інформаційної моделі лікування хворих з порушеннями ОРА у спеціалізованих закладах, що заснована на принципах об'єктивності, автоматизації та мінімізації витрат часу. При розробці даної моделі був використаний досвід реабілітаційно-відновлювального лікування (РВЛ) у санаторії «Металург».

Результати й обговорення. Сформулюємо, як визначено у [1], вихідні дані для побудови структурноінформаційної моделі МІС РВЛ хворих із патологією рухового апарату. Їх перелік матиме такий вигляд:

1. Вік хворого - до 40 років; від 40 до 60 років; більше 60 років. Пропонована градація віку обумовлена різною динамікою відновлення рухових функцій у людини, в т. ч. у постінсультних хворих.

2. Тривалість захворювання - до 1 року; від 1 до 3 років; більше 3 років. Такий розподіл дозволяє виявити і оцінити можливість зворотності патогенетичного процесу.

3. Характер рухових порушень: порушення рухової функції за тонічним типом; порушення рухової функції за паретичним типом; контрактура (як ускладнення); екстрапірамідні порушення.

За основний критерій визначення характеру порушень рухової функції можна прийняти наявність у неврологічному статусі провідного синдрому ураження рухової функції, що визначається:

1) психоемоційним станом: емоційно-поведінкова пасивність; емоційно-поведінкова активність; превентивно-захисна вегетативна активність; життєво-соціальна активність.

2) супутніми захворюваннями: серцево-судинної системи; інші захворювання центральної (ЦНС) і периферійної нервової системи; ендокринної системи та шлунково-кишкового тракту.

Для пацієнтів старше 60 років, для яких характерна наявність загального і церебрального атеросклерозів, у МIC передбачено додаткове застосування медикаментозної терапії антисклеротичної дії.

Група хворих із захворюваннями серцево-судинної системи отримує додатково комплекс лікарських впливів, що включають коронаророзширюючі, антигіпертензивні й інші медикаменти.

Обов'язковими для всіх груп хворих з порушеннями рухової активності є заняття лікувальною фізкультурою як самостійно, так і в кабінетах ЛФК під наглядом лікарів і тренерів.

Додаткова медикаментозна терапія постінсультних хворих здійснюється суворо індивідуально з урахуванням віку, тривалості і характеру захворювання, призначених фізіотерапевтичних і бальнеологічних процедур. На рисунку представлена структурно-

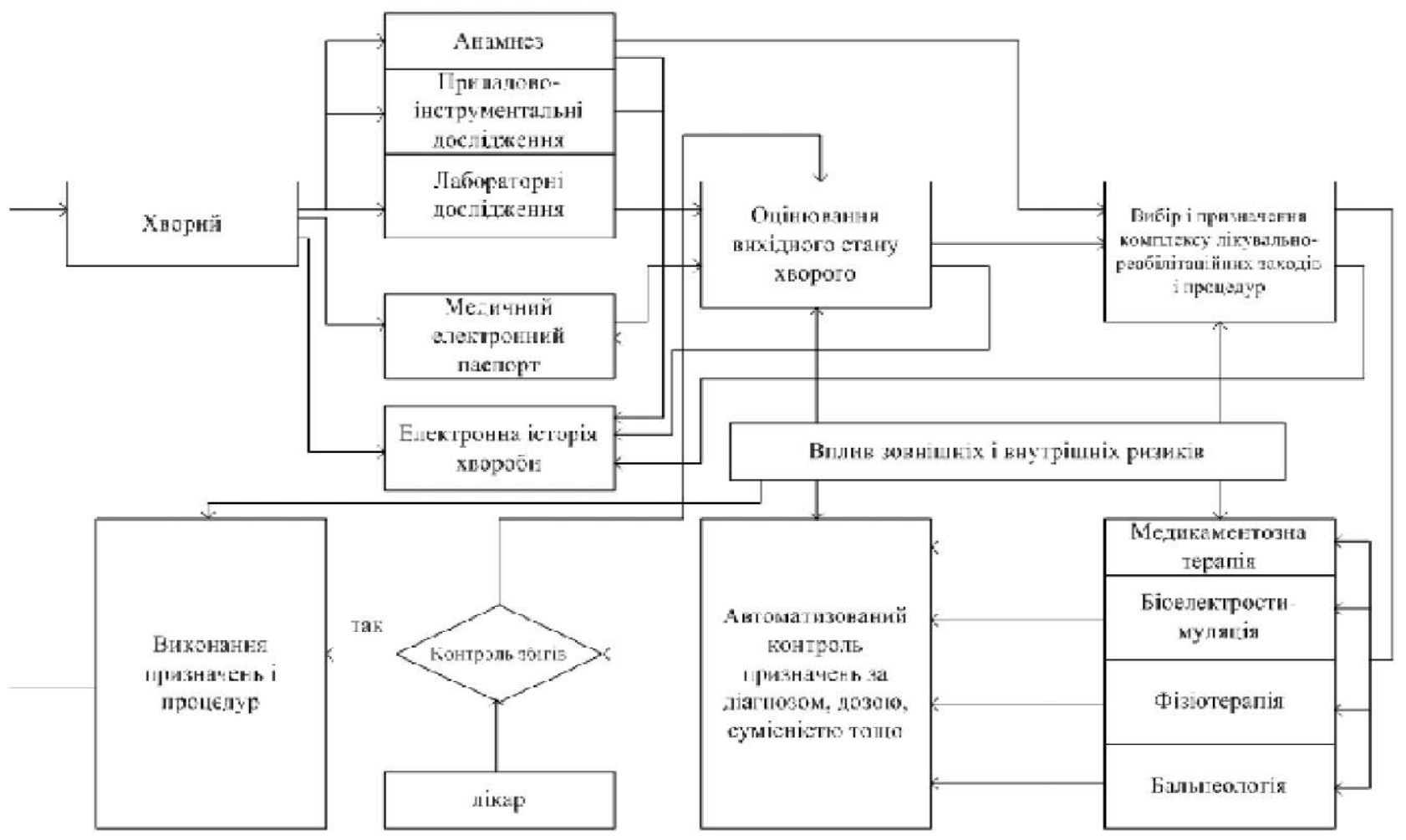

Puc. 1. Структурно-інформаційна модель МІС реабіттаційно-відновлювального лікування хворих із патологією ОРА. 
інформаційна модель МІС реабілітаційно-відновного лікування хворих із патологією ОРА.

Запропонована модель передбачає такі етапи (режими) функціонування МIC: проведення приладовоінструментальних і лабораторних досліджень, уточнення анамнезу; оцінювання вихідного стану хворого; вибір і призначення лікувально-реабілітаційних заходів і процедур, як в комплексі, так і за окремими напрямками лікування, автоматизований контроль призначень на відповідність діагнозу, дозуванню, сумісності медикаментів тощо; додатковий контроль - контроль збігів результатів автоматизованого контролю і діагнозу лікаря; індивідуальне виконання призначень і процедур для кожного хворого.

Система використовує підсистему кількісної діагностики рухової функції постінсультних хворих, в основу якої покладено визначення кількості діагностичних одиниць реабілітації (ДОР), що дозволяє проаналізувати зміни стану хворого за кількісними характеристиками ДОР і отримати представлення про хід та якість лікування. При цьому швидкість приросту ДОР за одиницю часу характеризує ефективність лікування або реабілітації [2].

Підсистема біоелектричної стимуляції, що $є$ невід'ємною частиною МІС РВЛ хворих із патологією рухового апарату, забезпечує вибір і параметри стимуляції, що базується на сукупності показників, об'єднаних в чотири групи. Цими групами є:

1) група фізіологічних показників, які характеризують суб'єктивне сприйняття сигналів і їх вплив на перебіг процесів в організмі хворого;

2) група функціональних показників, які характеризують якість виконаних пацієнтом рухів (сила i швидкість скорочення, кількість, точність та обсяг рухів, межа втомлюваності);

3) група технічних показників (кількість режимів, можливість регулювання управляючих сигналів тощо);

4) група показників, що дозволяють нейтралізувати або мінімізувати негативний вплив внутрішніх i зовнішніх ризиків на якість лікувально-реабілітаційного процесу [3].

Наявність в анамнезі після перенесення хворим інсульту змін енергетичних витрат на збудження і скорочення скелетних м'язів можна поділити на дві групи: аперіодичні зміни величини (потужності) стимулу в процесі відновлювального лікування і гармонічні (коливальні) зміни величини стимулу в процесі відновлювального лікування і коливальні зміни. Саме коливальні зміни свідчать про те, що кількість сеансів лікування необхідно визначати індивідуально для кожного хво- рого залежно від перебігу відновлювального процесу реакцій організму на нього. В такій ситуації додатковим критерієм оцінювання ефективності лікування і реабілітації можна вважати динаміку зміни енергетичних витрат, необхідних для збудження і скорочення м'язових груп при рухових розладах.

Виходячи із представленої системи чотирьох груп показників, експериментальних даних та аналізу історій хвороб, можна запропонувати в якості біоелектричних стимулів прямокутні імпульсні сигнали, уніполярні і біполярні, тривалістю 0,12-0,16 мс і частотою повторення 70-220 Гц, а також синусоїдальні сигнали частотою 1,8-5,8 кГц. Максимальне значення імпульсного струму стимуляції повинно складати не менше 50 мА при опорі 2 кОм. Такі параметри стимулів приблизно відповідають за тривалістю хронаксії параметрам більшості скелетних м'язів людини в нормі і при деяких видах патології, а за частотою - порогу сумації одиничних скорочень і переходу в тетанус.

Вибір частоти синусоїдальних сигналів 1,8-5,8 кГц обумовлений тим, що: по-перше, саме на цих частотах межі комфортної зони (і пов'язана з ними точність дозування) забезпечують найкращі функціональні показники; по-друге, на цих частотах створюються найкращі умови для протікання електричного струму через живу тканину [2].

Сутність механізму покращення рухових функцій у постінсультних хворих при застосуванні біоелектричних стимуляційних впливів полягає в стимуляції м'язової активності з одночасним відповідним руховим образом, наближеним за своєю середовищно-часовою структурою до реального руху. Безумовною перевагою такої методики стимуляції є потік нових аферентних імпульсів, які поступають у вищі відділи ЦНС, що сприяє покращенню (відновленню) нормальних зв'язків між центром і периферією нервової системи. Фізіологічною основою появи нових рухових навичок варто вважати умовно-рефлекторний механізм, коли, за допомогою каналів біологічного зворотного зв'язку, поява рухових навичок нового типу координується за рахунок пропріорецептивної сигналізації, а також включення інших аналізаторів (наприклад, зорового аналізатора, що є важливим при формуванні динамічного стереотипу).

Висновок. Новизною представленої структурноінформаційної моделі МІС РВЛ хворих із патологією рухового апарату є введення дворівневого контролю медичних призначень. Перший рівень контролю - це автоматизований контроль процедур на відповідність діагнозу, а другий - контроль збігів результатів пер- 
шого рівня і рішень, прийнятих лікарем, що практично повністю виключає або максимально зменшує ризики помилкового призначення лікарських засобів і встановлення невірного діагнозу, а також автоматизує процес призначення фізіотерапевтичних, бальнеологічних і біоелектростимулюючих процедур.

\section{Лiтература}

1. Болгов М. Ю. Медицинские информационные системы и телемедицина / М. Ю. Болгов // Медична техніка. - 2008. - oㅡ $>2$ (3). - С. $12-15$.

2. «Миотон» в управлении движениями / [Л. С. Алеев, М. -

И. Вовк, В. Н. Горбанёв, А. Б. Шевченко]. - К. : Наукова

думка, 1980. - 144 с.

3. Evaluation and treatment of erectile dysfunction / [M. Albersen, K. B. Mwamukonda, A. W. Shindel, T. F. Lue]/ / Medical Clinics ofNorth America. — 2011. — Vol. 95 (1). P. 201-212. 